\title{
THE INFLUENCE OF THE THYROID GLAND ON ANTITOXIN PRODUCTION IN DIFFERENT SPECIES
}

\author{
BY JENNIFER SHEWELL AND D. A. LONG* \\ National Institute for Medical Research, Mill Hill, London, N.W. 7 \\ INTRODUCTION
}

The administration of thyroxine to guinea-pigs before and during immunization results in an increased titre of circulating antitoxin (Long \& Shewell, 1955). Hypothyroidism, induced by prolonged treatment with propylthiouracil, invariably slightly impairs antitoxin formation in this species (unpublished observations). In direct contrast to these findings, comparable experiments with rats showed that thyroxine-treated rats produced less circulating antitoxin than control animals. These opposite effects are particularly interesting in that guinea-pigs and rats belong respectively to groups of species termed cortisone-resistant and cortisone-sensitive (Shewell \& Long, 1956), and it was decided therefore to study fully the influence of the thyroid gland on the antibody-forming capacity of representatives of these two groups of animals. In each case, the effects of surgical thyroidectomy, 'chemical thyroidectomy' and thyroxine administration on the production of antitoxin in response to a soluble antigen were investigated.

Animals

METHODS

The species investigated, and their approximate initial weights, were:

$\begin{array}{lr}\text { Albino guinea-pigs (Hampstead strain) } & 450 \mathrm{~g} . \\ \text { Hooded rats } & 200 \mathrm{~g} . \\ \text { Albino mice (Parkes strain) } & 25 \mathrm{~g} . \\ \mathrm{C}_{3} \mathrm{H} \text { mice } & 25 \mathrm{~g} . \\ \text { Himalayan rabbits } & 1500 \mathrm{~g} .\end{array}$

Male animals were used in all cases, to avoid any variation in thyroid activity during different phases of the oestrous cycle (Soliman \& Reineke, 1954; Feldman, 1956). Rats and mice were fed on diet 41 (Bruce \& Parkes, 1949), and guinea-pigs and rabbits on diet $18 \mathrm{~A}$ (Long \& Martin, 1956) supplemented with hay. In addition, guinea-pigs were given cabbage as a source of ascorbic acid. All animals were supplied with tap-water ad libitum.

\section{Immunization}

In all experiments the immunizing agent was an alum-precipitated toxoideither tetanus toxoid (XW 2044) or diphtheria toxoid (Ba 536). The hyperthyroid and hypothyroid states to be investigated were all induced before the first injection of antigen. A saline suspension of alum-precipitated toxoid, $2.5 \mathrm{Lf} / \mathrm{kg}$. body weight,

* Present address: Medical Research Department, The Wellcome Foundation Ltd, The Wellcome Building, London, N.W. 1, England. 
was injected into the adductor muscles of the right hind leg, and a second injection of the same dose was made into the same site 28 days later. This technique has the advantage that variation in the immune response between animals is diminished. Ten days after the secondary response blood samples were taken for antitoxin assay. Individual serum samples were titrated for tetanus antitoxin using the mouse in vivo technique, against a laboratory standard tetanus toxin. Diphtheria antitoxin assays were carried out using a modification of the classic multiple Schick method (see Long \& Shewell, 1955), and the Römer \& Sames' (1909) intradermal method.

\section{Thyroxine administration}

A saline suspension of L-thyroxine (B.D.H.) was injected subcutaneously twice a week for 3-6 weeks before immunization. The dose given was adjusted for each animal, and was enough to prevent any gain in weight but not so great as to cause significant weight loss. Initial doses of thyroxine were $0.1 \mathrm{mg} . / \mathrm{kg}$. body weight for guinea-pigs, $0.02 \mathrm{mg} . / \mathrm{kg}$. rats, $0.2 \mathrm{mg} . / \mathrm{kg}$. mice and $0.5 \mathrm{mg}$. $/ \mathrm{kg}$. rabbits.

\section{Propylthiouracil administration}

$n$-Propylthiouracil was given in the drinking water, with $3 \%$ cane sugar solution added to make it acceptable to the animals. The amount of water drunk each day was recorded, and varying concentrations of propylthiouracil used to ensure that each animal's intake was about $200 \mathrm{mg}$. $/ \mathrm{kg}$. body weight $/$ day. Control animals were given $3 \%$ cane sugar solution.

\section{Surgical thyroidectomy}

Guinea-pigs and rabbits were anaesthetized with nembutal and ether, rats with ether and mice with intraperitoneal avertin (I.C.I.) for the surgical procedures. There were no operative deaths with rats, rabbits or guinea-pigs. Mouse thyroidectomy was associated with a $30 \%$ mortality, and for this experiment $\mathrm{C}_{3} \mathrm{H}$ mice, reputedly better able to withstand surgical intervention (Lostroh \& Jordan, 1955), were used in preference to Parkes mice. There was still, however, a $10 \%$ mortality rate. No animals died during the period of immunization, and all maintained good condition.

Immediately post-operatively, guinea-pigs were given $1 \%$ sterile calcium gluconate solution intraperitoneally, and all parathyroid-thyroidectomized animals were maintained on $1 \%$ calcium gluconate solution as drinking water.

\section{Radiothyroidectomy}

A group of ten guinea-pigs was also rendered hypothyroid with two doses of $1 \mathrm{mc}$. of ${ }^{131} \mathrm{I}$ sodium iodide in saline injected intraperitoneally, given at an interval of one week.

Completeness of destruction of thyroid tissue in these animals, and in the surgically thyroidectomized guinea-pigs, was checked during immunization by measuring the thyroidal uptake of a tracer dose of $10 \mu \mathrm{c}{ }^{131} \mathrm{I}$. The absence of a higher neck than thigh count indicated the absence of functioning thyroid tissue. 


\section{Post-mortem analysis}

Blood samples were taken from the heart under chloroform anaesthesia, and after killing with chloroform the control and treated animals were examined. Surgically thyroidectomized animals were checked for completeness of removal of thyroid tissue, any possibly functioning remnant being examined histologically. The thyroid glands of propylthiouracil-treated, thyroxine-treated and control animals were dissected out and weighed fresh on a torsion balance. The adrenal glands, and the thymus glands of rats, rabbits and mice were also dissected out and weighed. Organ weights were calculated as relative to $100 \mathrm{~g}$. body weight.

\section{RESULTS}

\section{Circulating antitoxin levels}

Hyperthyroidism. The effect of thyroxine treatment, while immunization was in progress, was to decrease the amount of circulating antitoxin found in the blood of rats, rabbits and mice. This effect is in marked contrast to the enhancing effect of thyroxine on antitoxin production in the guinea-pig. The difference between titres in the control and treated groups of rats $(P \bumpeq 0.01)$ and rabbits $(P<0.001)$ was significant. The effect of thyroxine on the circulating antitoxin level of mice, while marked, was only of borderline significance $(0.05<P<0.1)$ owing to the inaccuracy of the assay method for low-titre antitoxins combined with large variation between the responses of individual animals. The results of the assays are set out in Table 1.

Hypothyroidism. Propylthiouracil-treated rats and mice produced significantly more circulating tetanus antitoxin than their controls $(P<0.001)$. Treatment with propylthiouracil had no effect on circulating antitoxin levels in the rabbit.

Surgical thyroidectomy in the guinea-pig resulted in a slight decrease of circulating antitoxin of borderline significance $(0.02<P<0.05)$. This result was obtained both after surgical removal of the gland and following radiothyroidectomy. Thyroidectomized mice $(0.001<P<0.01)$ and rats $(P<0.001)$, on the other hand, showed markedly higher levels of circulating antitoxin than their intact controls. Thyroidectomy in the rabbit, in contrast to the lack of effect of thiouracil treatment, resulted in an increased production of diphtheria antitoxin. At post-mortem examination one rabbit was found to have developed a large amount of functional thyroid tissue from a 'rest'. The antitoxin titre in the serum of this rabbit was $2 \cdot 5 \mathrm{i} . \mathrm{u} . / \mathrm{ml}$., which is well within the range of titres in the control rabbits (Table 1).

\section{Organ weights}

Thyroid gland weights. The thyroid glands of all propylthiouracil-treated animals (Table 2) were significantly heavier than those of their controls, and showed the typical hyperplastic appearance resulting from administration of this type of goitrogenic agent. The thyroid glands of the propylthiouracil-treated rabbits, however, still showed some colloid material, although its staining reaction was less 

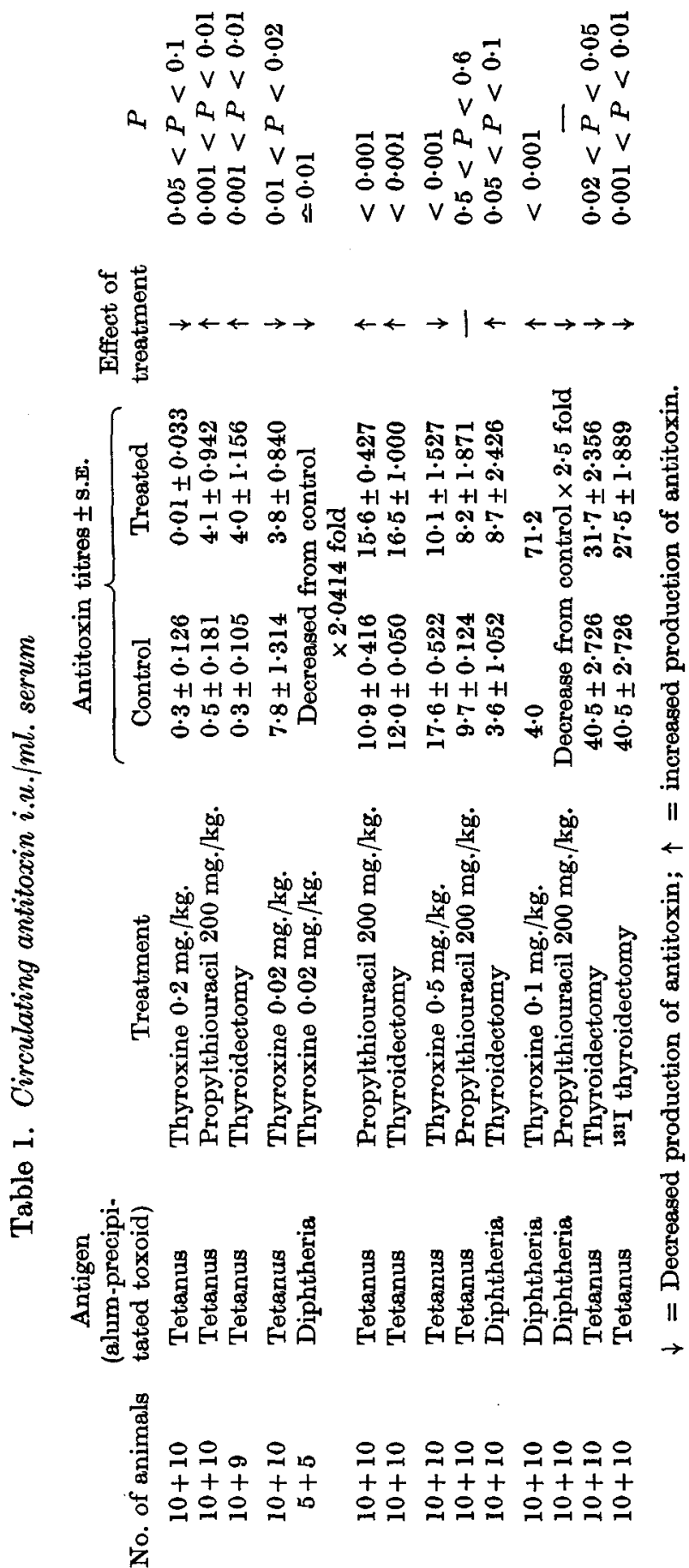

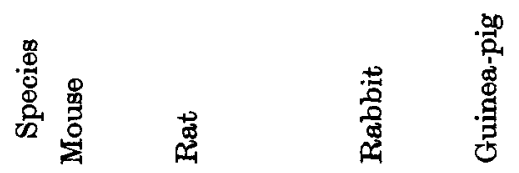


than that of those from control animals, suggesting that the glands were only responding slightly to the drug.

The thyroid glands from thyroxine-treated animals were pale in colour, due to the marked degree of colloid storage and inactivity of the glands.

Table 2. Thyroid glands weight mg./100 g. body weight.

Effect of propylthiouracil $200 \mathrm{mg} . / \mathrm{kg} . /$ day

\begin{tabular}{lcccc}
\multicolumn{1}{c}{ Species } & Control \pm s.E. & Treated \pm s.E. & $\begin{array}{c}\text { Effect of } \\
\text { treatment }\end{array}$ & $P$ \\
Mouse $(10+10)$ & $10.9 \pm 0.817$ & $38 \cdot 1 \pm 4 \cdot 116$ & Inc. wt. & $<0.001$ \\
Rat $(10+10)$ & $8 \cdot 4 \pm 1.031$ & $29 \cdot 9 \pm 1 \cdot 610$ & Inc. wt. & $<0.001$ \\
Rabbit $(10+10)$ & $8 \cdot 1 \pm 0.288$ & $30.7 \pm 1.851$ & Inc. wt. & $<0.001$
\end{tabular}

Adrenal gland weights. Thyroxine administration resulted in an increased adrenal weight in all the species examined, although this effect was of only borderline significance $(0.05<P<0.1)$ in the mouse (Table 3). Adrenal hypertrophy was markedly significant in rats, rabbits and guinea-pigs $(P<0.001)$.

Table 3. Adrenal glands weight mg./100 g. body weight

\begin{tabular}{|c|c|c|c|c|}
\hline Species & Control \pm s.E. & Treated \pm S.E. & $\begin{array}{c}\text { Effect of } \\
\text { treatment }\end{array}$ & $\boldsymbol{P}$ \\
\hline \multicolumn{5}{|c|}{ Effect of thyroxine (for dosage see text) } \\
\hline Mouse $(10+10)$ & $12 \cdot 9 \pm 0 \cdot 755$ & $15 \cdot 0 \pm 0.939$ & Adrenal hypertrophy & $0.05<P<0.1$ \\
\hline Rat $(10+10)$ & $14 \cdot 8 \pm 0 \cdot 434$ & $17 \cdot 6 \pm 0 \cdot 713$ & Adrenal hypertrophy & $0.001<P<0.01$ \\
\hline $\begin{array}{l}\text { Rabbit } \\
(10+10)\end{array}$ & $14 \cdot 5 \pm 1 \cdot 115$ & $22 \cdot 0 \pm 1 \cdot 321$ & Adrenal hypertrophy & $<0.001$ \\
\hline $\begin{array}{c}\text { Guinea-pig } \\
(10+10)\end{array}$ & $48 \cdot 4 \pm 1 \cdot 735$ & $102 \cdot 6 \pm 4 \cdot 526$ & Adrenal hypertrophy & $<0.001$ \\
\hline \multicolumn{5}{|c|}{ Effect of propylthiouracil $200 \mathrm{mg} . / \mathrm{kg} . /$ day } \\
\hline Mouse $(10+10)$ & $14 \cdot 8 \pm 0.973$ & $14 \cdot 7 \pm 0 \cdot 887$ & None & - \\
\hline Rat $(10+10)$ & $12 \cdot 2 \pm 0 \cdot 693$ & $12 \cdot 9 \pm 0.588$ & None & - \\
\hline Rabbit $(10+10)$ & $14 \cdot 0 \pm 0 \cdot 862$ & $15 \cdot 6 \pm 1 \cdot 243$ & None & - \\
\hline \multicolumn{5}{|c|}{ Effect of thyroidectomy } \\
\hline $\begin{array}{c}\text { Mouse }\left(\mathrm{C}_{3} \mathrm{H}\right) \\
(10+9)\end{array}$ & $17 \cdot 2 \pm 1.949$ & $20 \cdot 9 \pm 2 \cdot 069$ & $\begin{array}{l}\text { Inc. wt.--not } \\
\text { significant }\end{array}$ & $>0.2$ \\
\hline Rat $(10+10)$ & $14 \cdot 7 \pm 0 \cdot 454$ & $12 \cdot 5 \pm 0 \cdot 735$ & Dec. wt. & $0.01<P<0.02$ \\
\hline $\begin{array}{l}\text { Rabbit } \\
(10+10)\end{array}$ & $14 \cdot 9 \pm 1 \cdot 230$ & $16 \cdot 9 \pm 1 \cdot 535$ & $\begin{array}{l}\text { Inc. wt.-not } \\
\text { significant }\end{array}$ & $>0 \cdot 3$ \\
\hline $\begin{array}{c}\text { Guinea-pig } \\
(10+10)\end{array}$ & $41 \cdot 4 \pm 2 \cdot 078$ & $44 \cdot 3 \pm 3 \cdot 672$ & None & - \\
\hline
\end{tabular}

The effects of thyroidectomy on adrenal gland weight were not consistent. Propylthiouracil treatment had no significant effect in any species. Surgical thyroidectomy resulted in a decreased adrenal weight in mice and rats, but this effect was only significant in the rat $(0.01<P<0.02)$, and was without significant effect in the rabbit and guinea-pig. 


\section{DISCUSSION}

The results reported here show that a difference with regard to the effect of the thyroid hormone on the production of antitoxin may be demonstrated between the guinea-pig on the one hand, and rats, rabbits and mice on the other. These diametrically opposed effects strengthen the distinction drawn earlier between two groups of animal species, namely: man, rhesus monkey and guinea-pig, and rat, rabbit, mouse and ferret, on the basis of their response to large doses of cortisone acetate (Shewell \& Long, 1956). Other aspects of this difference between species, including ability to synthesize ascorbic acid and sensitivity to bacterial allergens, have been discussed elsewhere (Long, 1957). An important sequel to the concept of cortisone 'sensitive' and 'resistant' species has been the demonstration by Gerwing, Long \& Pitt-Rivers (1958), that bacterial exotoxins stimulated both adrenocortical and thyroid activity in the rhesus monkey and guinea-pig, but produced increased adrenal cortical activity with a reciprocal decrease in thyroid activity in the rat, mouse and rabbit.

This difference between the immune response of these two groups of species is in keeping with, and elucidates, the conflicting results reported in the literature on the influence of the thyroid gland on antibody production using different experimental animals. Thus, Ecker \& Goldblatt (1921) found that thyroidectomized rabbits produced higher haemolysin titres than their controls, and Houssay \& Sordelli (1921) found greater agglutinin production in thyroidectomized horses and rabbits, but Nilzén (1957) observed lower agglutinin titres in thyroidectomized guinea-pigs than in intact controls. These results are all in agreement with those reported here for tetanus and diphtheria antitoxin production. Not only thyroidectomy, but also experimental production of the hyperthyroid state, have opposite effects on antitoxin production in the guinea-pig from those seen in the rat, rabbit and mouse.

In all the species examined, thyroxine administration produced a relative increase in adrenal gland weight. Presumably the administration of exogenous thyroxine decreased the output of thyrotrophin from the anterior pituitary gland, and this, according to Harris's (1955) hypothesis of the reciprocal relationship between the production of thyrotrophin and corticotrophin, would result in an increased production of corticotrophin and an increase in the size and activity of the adrenal gland. In animals such as the rat, mouse and rabbit, whose antitoxin production is depressed by an increase in circulating corticosteroids, increased adrenal activity would impair antitoxin production, and this hypothesis provides a simple explanation of the depressing effect of thyroxine on circulating antitoxin in these species. The enhanced antitoxin production exhibited by these animals, when thyroidectomized, might then result from the converse effect-removal of the inhibiting action of corticosteroids on antitoxin production when adrenocortical activity is diminished-as it would be if the increased thyrotrophin production in thyroidectomy takes place at the expense of corticotrophin output. The literature on adrenal atrophy after surgical or chemical thyroidectomy in different species is contradictory (see Brown-Grant, 1958) but variation between animals is great, 
and adrenocortical activity might be reduced without adrenal atrophy being unequivocably demonstrated. Adrenalectomized rats and rabbits are better producers of haemolysins and agglutinins than are intact animals (Jaffe \& Marine, 1924; Také \& Marine, 1923).

In the guinea-pig, however, antibody formation is unimpaired by the administration of cortisone acetate in doses as large as $50 \mathrm{mg} . / \mathrm{kg}$. body weight (Shewell \& Long, 1956), and this animal responds to an increased level of circulating thyroid hormone, not by producing less antitoxin, but by producing more. This effect is obtained only if the pancreas is intact (Long \& Shewell, 1955); it may be that the hypertrophy of the islets of Langerhans induced by thyroxine is more important, from the point of view of altering rates of antitoxin formation, than thyroxineinduced adrenal hypertrophy in this cortisone-resistant species.

\section{CONCLUSIONS}

The division that has been made between two groups of animal species on the basis of their response to one example of experimental hormonal imbalance-the administration of large doses of cortisone acetate-appears to be maintained when the influence of the thyroid gland on antitoxin formation is studied.

The cortisone-resistant guinea-pig has a higher level of circulating antitoxin when hyperthyroid, but produces less antitoxin when rendered hypothyroid by surgery, ${ }^{131} \mathrm{I}$ administration or propylthiouracil treatment. The rat, mouse and rabbit -cortisone-sensitive animals-produce, in contrast, more circulating antitoxin than their controls when thyroidectomized. The hyperthyroid state in these animals impairs their antibody-forming capacity. These results are the more striking because bacterial stress stimulates thyroid activity in 'cortisone-resistant' species, and depresses thyroid activity in 'cortisone-sensitive' species, and yet in both cases antitoxin production is assisted.

\section{SUMMARY}

1. The influence of the thyroid gland on the production of antitoxins to two alum-precipitated bacterial exotoxins has been investigated in different animal species.

2. Rats, rabbits and mice produce more circulating antitoxin when thyroidectomized, and less when made hyperthyroid by thyroxine administration, than control animals.

3. Guinea-pigs produce slightly less antitoxin when thyroidectomized, and markedly more when thyroxine treated, than control animals.

We are grateful to Dr J. S. F. Niven for histological examination of tissues, and to Miss M. V. Mussett, B.Sc., for statistical analyses. The alum-precipitated tetanus toxoid XW 2044, and tetanus toxin XW 1322, were kindly supplied by Miss Mollie Barr, M.Sc., of the Wellcome Research Laboratories, Beckenham, Kent, and we are also grateful to Mr P. Rodican of the Lister Institute, Elstree, for a supply of tetanus toxin 829 . 


\section{REFERENCES}

Brown-GraNt, K. (1958). J. Endocrin. 17, 197.

Bruce, H. M. \& Parkes, A. S. (1949). J. Hyg., Camb., 47, 202.

ECKRR, E. \& GoldBLATT, H. (1921). J. exp. Med. 34, 275.

Feldman, J. D. (1956). Amer. J. Physiol. 184, 369.

Gerwing, Julta, Long, D. A. \& Pitt-Rivers, Rosatind (1958). J. Physiol. 144, 229.

Harris, G. W. (1955). Ciba Foundation Colloquia on Endocrinology, 8, 531.

Houssay, B. A. \& Sordelit, A. (1921). C.R. Soc. biol., Paris, 85, 679, 1220.

JAFFE, H. L. \& MARINE, D. (1924). J. infect. Dis. 35, 334.

Long, D. A. (1957). Int. Arch. Allergy, Basel, 10, 5.

Long, D. A. \& Marin, A. J. P. (1956). Lancet, i, 464.

Long, D. A. \& Shewell, Jennifer (1955). Brit. J. exp. Path. 36, 351.

Lostroh, A. J. \& Jordan, C. W. (1955). Proc. Soc. exp. Biol., N.Y., 90, 267.

Nuzten, A. (1957), Acta allerg., Kbh., 11, 45.

Römer, P. H. \& SAMts, TH. (1909). Z. ImmunForsch. 3, 344.

Shewerl, Jennifer \& Long, D. A. (1956). J. Hyg., Camb., 54, 452.

Solman, F. A. \& Renneke, E. P. (1954). J. Endocrin. 10, 305.

TAKÉ, N. M. \& Marine, D. (1923). J. infect. Dis. 33, 217.

(MS. received for publication 4. ח. 59) 